\title{
Forming a culture of interpersonal relationships of senior preschoolers by means of art and play activities
}

\section{Formando uma cultura de relacionamento interpessoal de crianças em idade pré-escolar por meio de atividades artísticas e lúdicas}

\section{Formar una cultura de relaciones interpersonales de preescolares mayores mediante el arte y las actividades lúdicas}

\author{
Natalia Sergeevna Yushchenko ${ }^{1}$ (D) Elena Borisovna Pokivaylova ${ }^{1}$ (D), \\ Lena Igorevna Cheshenko ${ }^{1}$ (D) Olga Victorovna Ershova ${ }^{2}$ (D) Vladimir Manuilov ${ }^{3}$
}

\footnotetext{
${ }^{1}$ Russian State Social University, Moscow, Russia.

${ }^{2}$ Moscow City University, Moscow, Russia.

${ }^{3}$ Military University Russian State, Moscow, Russia.

\section{Corresponding author:}

Natalia Sergeevna Yushchenko

Email: ns.yushchenko@mail.ru
}

How to cite: Yushchenko, N. S., Pokivaylova, E. B., Cheshenko, L. I., Ershova, O. V., \& Manuilov, V. (2021). Forming a culture of interpersonal relationships of senior preschoolers by means of art and play activities. Revista Tempos e Espaços em Educação, 14(33), e16135. http://dx.doi.org/10.20952/revtee.v14i33.16135

\begin{abstract}
The article is concerned with an urgent issue of art pedagogy, namely, the socialization and aesthetic development of senior preschoolers through group play activities. The authors of the article have highlighted the importance of individual and personal characteristics of children of this age when they are involved in joint creative activity and group interaction. Particular attention is paid to the culture of communication and interaction of senior preschoolers with their peers and teachers. At the same time, the study covers the issues of realizing the creative potential of senior preschoolers through art and games. A separate direction of this pedagogical research of senior preschoolers is the comprehensive personal diagnostics of such children and the corresponding typology of their personality. Based on the characteristics of each type of child, the authors have proposed the main pedagogical strategies for the formation of a culture of interpersonal relationships that can be used in various programs of aesthetic education and development of senior preschoolers. The article also highlights the corresponding typology of educational games assessed as a condition for forming scientifically grounded technologies of psychological, spiritual and moral development of senior preschoolers. The study might be of interest to a wide range of specialists.
\end{abstract}

Keywords: Culture. Art and play activity. Development. Personality type. Senior preschooler. 


\section{RESUMO}

O artigo trata de uma questão urgente da pedagogia da arte, a saber, a socialização e o desenvolvimento estético de crianças em idade pré-escolar por meio de atividades lúdicas em grupo. Os autores do artigo destacaram a importância das características individuais e pessoais das crianças desta idade quando estão envolvidas em atividades criativas conjuntas e interação em grupo. É dada especial atenção à cultura de comunicação e interação dos pré-escolares seniores com seus colegas e professores. Ao mesmo tempo, o estudo aborda as questões de realização do potencial criativo de crianças em idade pré-escolar por meio da arte e dos jogos. Uma direção separada desta pesquisa pedagógica de pré-escolares seniores é o diagnóstico pessoal abrangente de tais crianças e a tipologia correspondente de sua personalidade. Com base nas características de cada tipo de criança, os autores propõem as principais estratégias pedagógicas para a formação de uma cultura de relacionamento interpessoal que pode ser utilizada em diversos programas de educação estética e desenvolvimento de pré-escolares do último ano. $O$ artigo também destaca a tipologia correspondente de jogos educativos avaliados como condição para a formação de tecnologias cientificamente fundamentadas de desenvolvimento psicológico, espiritual e moral de pré-escolares seniores. $O$ estudo pode ser do interesse de uma ampla gama de especialistas.

Palavras-chave: Cultura. Arte e atividade lúdica. Desenvolvimento. Tipo de personalidade. Préescolar sênior.

\section{RESUMEN}

El artículo se ocupa de un tema urgente de la pedagogía del arte, a saber, la socialización y el desarrollo estético de los preescolares mayores a través de actividades de juego en grupo. Los autores del artículo han destacado la importancia de las características individuales y personales de los niños de esta edad cuando participan en actividades creativas conjuntas e interacción grupal. Se presta especial atención a la cultura de comunicación e interacción de los niños en edad preescolar de último año con sus compañeros y maestros. Al mismo tiempo, el estudio cubre las cuestiones relacionadas con la realización del potencial creativo de los niños en edad preescolar mayores a través del arte y los juegos. Una dirección separada de esta investigación pedagógica de los preescolares mayores es el diagnóstico personal integral de dichos niños y la tipología correspondiente de su personalidad. A partir de las características de cada tipo de niño, los autores han propuesto las principales estrategias pedagógicas para la formación de una cultura de relaciones interpersonales que pueden ser utilizadas en diversos programas de educación estética y desarrollo de preescolares mayores. El artículo también destaca la tipología correspondiente de juegos educativos evaluados como una condición para formar tecnologías científicamente fundamentadas de desarrollo psicológico, espiritual y moral de los preescolares mayores. El estudio puede ser de interés para una amplia gama de especialistas.

Palabras clave: Cultura. Actividad de arte y juego. Desarrollo. Tipo de personalidad. Niño en edad preescolar mayor.

\section{INTRODUCTION}

A preliminary consideration of the culture of interpersonal relationships of senior preschoolers shows that the decisive factor is the impact of the children's group as an environment for the primary socialization of their personalities. In this regard, it is crucial to develop a culture of interpersonal relationships based on situations of cooperation, partnership and informal contacts as dominant phenomena in a particular group activity.

The study of the personality traits of senior preschoolers is promising since all the aspects of their personality are considered that one way or another affect the culture of their interpersonal relationships. This means studying the personality of senior preschoolers in interpersonal interaction: typical features of perception, behavior, types of social and aesthetic activity, functional 
capabilities of an individual as an integral system, with the ability to build positive interpersonal relationships being one of its elements (Bozhovich, 1998; Loginova \& Samorukova, 1988; Leontev, 2009; Mukhina, 2010; Jung, 1995).

A variety of art and play activities influences the interaction of senior preschoolers. Children experiencing a deficit of such interaction most often find themselves in the risk group associated with insecurity in emerging social situations suppressing their individuality. As a result, they demonstrate social maladjustment and a lack of proper communication culture.

Accordingly, a differentiated approach to the study of these relations is required with due regard to the typological characteristics of children's personalities. The best organizational and methodological support of the corresponding empirical research is the complex diagnostics of the personality of senior preschoolers and the developed scenarios of art and pedagogical games.

In this regard, it is of particular importance to distinguish the corresponding groups of senior preschoolers based on the greatest psychological compatibility and predisposition to certain types of art and play activity, which has a positive impact on their personal development and relationships with others. It is also necessary to conduct complex diagnostics of senior preschoolers with due regard to interpersonal interaction. Thus, the relationships of senior preschoolers have many aspects, where the main component is the creative potential of their personality, whose implementation becomes the main condition for optimizing their interaction with the surrounding social environment.

\section{METHODS}

In the course of the study, we analyzed such parameters of the development of children's communicative activity as popularity in the peer group and among adults, the level of anxiety, aggressiveness, self-esteem, popularity and their role in society.

Dependencies between opportunities for self-realization were determined by the observation method with due regard to the type of personality revealed in the process of play activities and overcoming the existing deficits in development. The best solution is a psychological and pedagogical strategy focused on the strengths of children presented in the relevant psychotype. Like a "locomotive", it brings underdeveloped aspects of the preschooler's personality to the optimal level (Ilina, 2007; Kamenets, 2014).

The main objective of diagnosing these relationships was to study the ideas of children about their peers in the group developed in the process of interpersonal interaction.

The preparation of this research included the development of different survey strategies to define the choice of a particular child for joint games or leisure activities, as well as the determination of their personality types explaining this real or possible choice (Goffman, 2004; Kamenets, 2015; Grishina, 2001).

The personality types of children were determined in accordance with the diagnostic methods developed by scholars studying various groups of preschool children. Based on the characteristics identified during the diagnosis, an auxiliary complex of pedagogical games was formed for a certain type of child.

The typical features of these types are as follows:

"The Thinker-Dreamer". This type of preschooler is good at perceiving new information and new experience. They like beautiful toys, well-decorated interiors and colorful household items. They are interested in unusual stories and fantasies. They are capable of independent thinking, which to some extent compensates for the lack of verbal communication caused by the general underdevelopment of speech. They are individualists and extroverts.

"The Systematist-Organizer". These children are inclined to self-affirmation. They have certain volitional qualities and like to be in the spotlight. They can compensate for speech impairment with physical mobility, participation in games and activities where they demonstrate 
behavioral activity. They like to be involved in theatrical games, fantasize and come up with unexpected plots. They are extroverts and potential leaders who want others to follow them based on invented systemic information.

"The Gentle Idler". This type of preschoolers prefers a psychologically comfortable atmosphere but dislikes prolonged physical and mental stress. They are characterized by increased fatigability, therefore need timely pauses for rest. They are inclined to show their affection, sympathy and love for others in the form of touching, hugging, stroking, etc., which can somehow compensate for the lack of other means used in communication. These introverts especially love a festive and playful atmosphere.

"The Thinker-Researcher". These children think a lot and like to analyze and find connections between different phenomena. At the same time, they avoid self-demonstration and leadership, participate in group games and lessons sporadically. They like various puzzles and tasks that require the manifestation of mental abilities. Provided materials encouraging mental efforts, they can be left alone for a long time. Their culture of relationships can be developed if such introverted children are allowed to demonstrate the process and results of their mental activity to others.

"The Leader-Pedant". They aim at maintaining order and cleanliness. Characterized by a high level of self-organization, they like to design, "dig" into mechanisms and make crafts, which can be considered as a resource for their personal development through activity-based interaction with others. They are quite prideful and have the potential to become a leader. They want to be reckoned with but accept hierarchical relationships in the group. These preschoolers are introverts.

"The Creator of Beauty". These children like aesthetically organized space and beautiful things. They are often engaged in craft and fine art. Being silent, proud and emotionally reserved, these individualists possess advanced manual skills. Accordingly, psychomotor skills help to form an appropriate culture of relationships with peers. These introverts like outdoor games that demonstrate their dexterity, strength and courage.

"The Cheerful Player". These extroverts often smile and are in a good mood that conveys to others. Having a high level of sociability, they like games combined with humor and fun. At the same time, they are dependent on the atmosphere of love and friendship in their immediate environment. They willingly participate not only in active but also in cognitive games that require the ability to comprehend and analyze.

"The Idealist-Dreamer". This type is especially susceptible to literary, artistic and musical information. They have a potential gift for words. Accordingly, a culture of relationships in these children can be developed through the performance of songs and writing. Sometimes these introverts are prone to depressive states that can suddenly be replaced with eruptions of joy. These children are artistic but prefer roles characterized by sadness and melancholy. Their participation in theater activities is also recommended for speech development.

"The Demonstrator-Improviser". Characterized by increased vulnerability and resentment, such children need constant encouragement to achieve certain results. They like to demonstrate their emotional states in public in a fairly artistic form. Accordingly, giving a public speech can help them overcome the lack of communication. These extroverts like studying and easily accept logically structured information.

"The Sober Skeptic". They have developed imagination and the ability to implement its results in a visual form. Being rather practical, they do not like futile and unrealizable fantasies. They are inclined to self-expression using plastic and choreographic means which compensate for the lack of communication. However, these introverts do not like to openly show sympathy and avoid excessive sentimentality. They are ready to follow an authoritative leader.

"The Leader-Manipulator". This is the most uncontrollable personality type. Such children try to manipulate both peers and adults in their favor. Being quite charismatic, they feel good in front of a large number of people. These inborn leaders are also attention seekers. They are 
extremely mobile and restless, therefore need physical exercises, which can compensate for the undeveloped culture of interpersonal relationships. These children are extroverts.

"The Leader-Truth Lover". They are infused with a "sense of truth" and a tendency to denounce those who depart from it. They encourage the correct behavior and demonstrate their "correctness" to others. They are willing to engage in cognitive games that require erudition and awareness on various topics. Being inclined to leadership, these introverts often underestimate their abilities in the field of studying and public speaking, which often causes fear and increased anxiety. As a result, they need more attention to their problems in interpersonal relationships.

"The Adventurer-Conman". Being practical in preschool age, they demonstrate this quality and ingenuity associated with the achievement of certain results. They are initiative, independent and active. By inventing different art and play activities, they develop their own thinking and speech, which can be used for appropriate pedagogical work. These extroverts should be given more independence and the opportunity to show their own initiative.

"The Merciful Esthete". These children are very emotional, plastic and compassionate. They always help others. As a rule, they are musical and artistic. They like to play comic characters, as well as participate in outdoor and theater games. This tendency can be used to improve their interpersonal interaction. They are more guided by their own intuition than logic. These pronounced introverts live through their "feelings" and prefer to be friends with "everyone." These are born collectivists. They appreciate the beauty of nature, the world of things and good environmental design.

"The Assistant-Organizer". They show the ability to be observant in the material world. These children are constant in their hobbies but have a wide range of interests. They are especially sensitive to manifestations of humanism, honesty and truthfulness from others. They dislike improvisation and surprises, therefore feel much safer in situations developing in conformity with previously known scenarios, plans and programs. As a rule, they are very responsible in completing assignments. These extroverts like to help other children and teachers in organizing classes.

"The Truth Lover-Humanist". This type is characterized by sensitivity, compassion and the ability to understand others. They are pitying and can feel sorry for injustice in relation not only to themselves but also to others for a long time. They willingly provide aid to those who need it. They do not demonstrate enough self-love while loving others. To find their way in the world of objects, they need some help, i.e. they are a little "out of this world". These introverts are grateful to those who take care of them but are afraid of embarrassing the latter. They dislike public selfdemonstration. Art and play activity is more comfortable in a narrow circle of communication.

\section{RESULTS}

This diagnosis was considered after conducting sociometric procedures in the group to identify the relationship between senior preschoolers and their peers.

To select an interaction partner, the children were asked the following questions: "Who would you like to play with?", "Who would you like to visit?" "Who would you like to have as your classmate?", etc. We have analyzed the reasons for choosing children based on various grounds. The surveys of children were supplemented with a series of observations, as well as a pedagogical experiment on the role of group art and play activities. The results obtained were processed as the choices made by the children which were supplemented with appropriate conversations.

The results of studying relationships among children were divided into the following groups.

The first group consisted of children with the largest number of options ("stars");

The second group comprised the rest of the children who received one choice or another but were inferior to the "stars";

The third group included the children who had limited choices or no choice at all ("outsiders"). 
It is worth mentioning that the internal differentiation of senior preschoolers was based on general game programs available to one degree or another for all the children. However, the personality traits of preschoolers were not revealed.

A more differentiated diagnosis was conducted based on appropriate observation and study of senior preschoolers in accordance with their personality types. As a result, the corresponding typology of children and their psychologically compatible subgroups was tested and specified, which allowed us to form more detailed sociometry of their interpersonal relationships. Later we managed to develop appropriate scenarios of social interaction (Kadson \& Schaefer, 2001; Kipnis, 2002; Leutz, 1994; Moreno, 2001).

The first group of senior preschoolers having the greatest psychological compatibility included such psychotypes as the "Gentle Idler", "Thinker-Researcher", "Cheerful Player" and "Thinker-Dreamer".

This group was called "festive". Its important psychological feature is the desire to create a festive atmosphere in the group and ensure a variety of art and play events to develop cognitive and mental activities. These children are also receptive to visual art information. It is also important to avoid pronounced competition when organizing the art and play activity of this group; create situations of game cooperation and mutual assistance that these preschoolers need; entertain them the very process of game and search activity but not necessarily victory. As a result, children from this group might additionally develop a culture of relationships in festive and play situations.

The next group included such types of preschoolers as the "Leader-Pedant", "DemonstratorImproviser", "Idealist-Dreamer" and "Systematist-Leader". This group was called "performing" because the preschoolers showed a desire to actively participate in activities in which one can demonstrate some abilities to confirm their positive self-esteem and self-identification, which is especially important for children who do not always have such an opportunity.

One more group consisted of the "Adventurer-Conman", "Leader-Truth Lover", "LeaderManipulator" and "Sober Skeptic". It was called "leading" because it united preschoolers with a pronounced inclination to manifest their leadership qualities on various grounds: initiative, the love of truth, charisma, insight, etc. These foundations turned out to be important for children because they provided an opportunity to show their leadership qualities in art and play activities, requiring a minimum of verbal skills but developing the latter through play tasks built over different behavioral patterns.

The last group called "humanistic" consisted of the "Truth Lover-Humanist", "AssistantOrganizer", "Merciful Esthete" and "Creator of Beauty". The specific feature of this group was the ability to empathize, sympathize and understand others. For the children who fell into this group, this means getting an opportunity to listen and hear others, while showing attentiveness, empathy and involvement, which serves as an additional resource for the formation of a culture of interpersonal relationships. Accordingly, it is desirable to select art and play activities that develop situations of mutual understanding and cooperation.

Considering the structure of preschoolers, art and game interactions were divided into the corresponding subgroups having a high level of psychological compatibility.

To attain this end, the preschoolers were tested and surveyed using various methods. These polls clarified the wishes of children to participate in play activities with their peers, spend leisure time together or go to school. In addition, we managed to reveal the reasons for their choices. We conducted a systematic observation of the communication and interaction of senior preschoolers in the process of group play sessions, which supplemented and clarified the results of diagnostic conversations and surveys.

The number of options was determined through conversations and observations. We clarified the main criteria for such choices, their duration and stability. Consequently, all the children were divided into the following groups: 
Group 1 - the greatest psychological compatibility (manifests regularly and continuously); Group 2 - average psychological compatibility (manifests sporadically and for a short time); Group 3-minimum psychological compatibility or lack thereof (children avoid each other).

The above-mentioned compatibility was assessed in accordance with the implementation of psychotypes and the spontaneous unification of preschoolers into the corresponding subgroups. All in all, there were four subgroups: "festive", "performing", "leading" and "humanistic".

For clarity, we present the results obtained in Figure 1.

Figure 1. The distribution of children among subgroups (the number of the respondents, in \%).

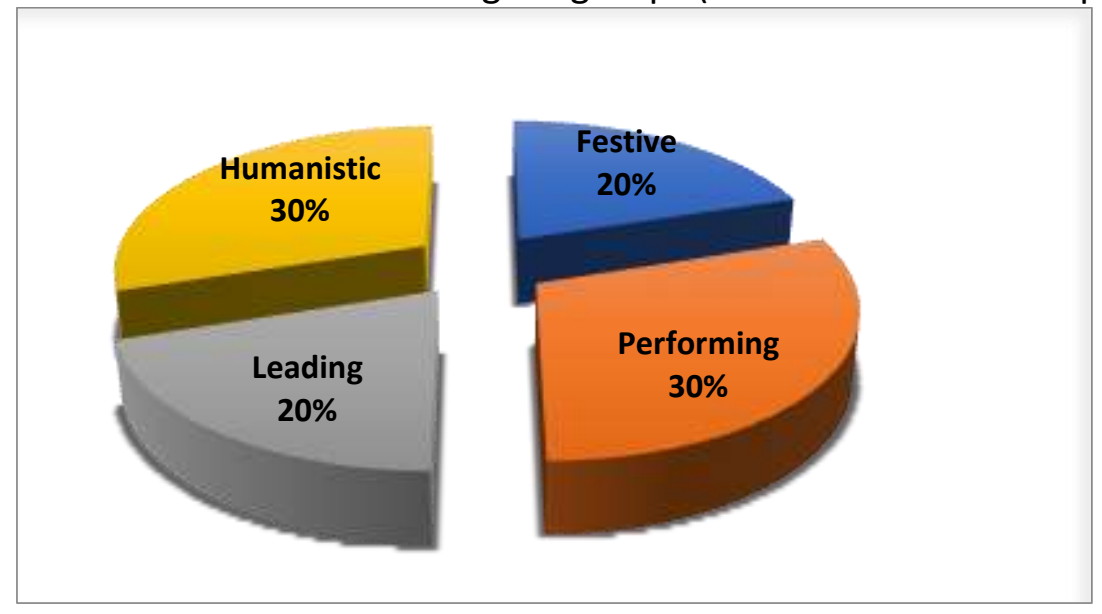

Within these subgroups, the children were attributed certain psychotypes in conformity with the corresponding development of their abilities for group interaction. In the process, the following problems were recorded: the weakening of visual contact with the surrounding reality; the lack of holistic perception; insufficient orientation in time and space; immunity to many logical and grammatical components of speech activity; the lack of consistency and awareness of outwardly expressed reactions; the violation of general and fine motor skills; uncoordinated physical actions; getting stuck in certain positions; unstable attention; fast psychophysiological exhaustion (Knyazeva, 2003; Elkonin \& Venger, 1988; Smirnova \& Kholmogorova, 2003).

\section{DISCUSSION}

Let us consider children in the subgroups we have identified. The "festive" subgroup ("Thinker-Dreamer" - 1; "Gentle Idler" - 3; "Cheerful Player" - 2):

The "Thinker-Dreamer" showed a lack of involvement in dialogues and a tendency to immerse in the inner world, even with external speech activity. Self-obsession hampered their orientation "towards others" due to insufficient attentiveness to external speech impacts; unwillingness to cooperate based on equal partnership; the lack of proper self-control in behavioral and speech activity. Accordingly, the least developed parameters were attention and motor skills, psychophysical endurance, coordination and physical movements, a variety of tactile sensations.

These deficits in personal development were overcome by providing a child with the opportunity to fantasize, indulge in intellectual and cognitive activity, which were demanded by the corresponding logic of game interaction in the group. The analysis of this psychotype has demonstrated that such a preschooler wanted to convey the results of their fantasizing in the corresponding behavioral activity to the other group members and involuntarily used accompanying speech and motor activity as a visual model.

The "Gentle Idler" was characterized by weak self-control and underdeveloped volitional qualities. Such children were not inclined to show initiative in interactions with others but were prone to emotional self-disclosure and tactile contact. Their least developed personality factors 
were as follows: phonemic and semantic susceptibility to speech, as well as psychophysical endurance. Encouraging these children to manifest their strengths in art and play activity through festive situations, involuntary expressions of positive emotions, tactile sensations and visual perceptions, these deficits were overcome, which was recorded by the corresponding diagnosis of activity in this group.

The "Cheerful Player". Although this psychotype has many positive qualities (the ability to create a playful and festive mood), they are not able to show the proper level of improvisation and spontaneity in speech interaction. The children were dependent on their emotional perception of others. They focused on external samples of interpersonal interaction and could skillfully use them in game-related situations. The least developed aspects of interpersonal interaction were fullfledged diction in oral speech and a variety of tactile sensations. To eliminate these shortcomings, this psychotype should rely on such strengths as visual perception, attention, memory, motor skills, spatial-temporal orientation, intellectual and cognitive activity.

The "performing" subgroup ("Demonstrator-Improviser" - 4; "Idealist-Dreamer" - 3; "Systematist-Leader"-2).

The "Demonstrator-Improviser". The least developed parameters were visual perception, attention and spatial-temporal orientation. These personality parameters were not developed due to the egocentrism of preschoolers, who were more concerned with their internal psychological states and self-demonstration rather than interest and attention to others. Accordingly, their art and play activities often did not fit into group interactions. There were attempts to win individually and take the lead in game scenarios to the detriment of the initial plot. This could not but affect the development of interpersonal relationships, in which there was a lack of desire for a full-fledged dialogue with the prevailing egocentric position.

To overcome such deficiencies, these children realized themselves in art and play activities that were psychologically comfortable for them. These were spatial-temporal orientation, phonemic and semantic sensitivity to speech, psychophysical endurance, intellectual and cognitive activity. According to the diagnostic observations, functioning in the theater and play space created for this purpose had a significant positive impact on these children in terms of solving the abovementioned problems of interpersonal interaction.

The "Idealist-Dreamer". The main problem of the preschoolers classified as this psychotype was their weak connection with reality and comparison of their play activity with real-life results. The deficits in personal development were visual perception, attention, memory, motor skills, spatial-temporal orientation, psychophysical endurance, coordination and a variety of physical movements. Hence, the observed tendency to depressive states, fears of unusual game situations and strangers largely hindered behavioral activity. As in the previous cases, these personality problems were solved thanks to the involvement of these children in the types of interaction that were most favorable for their self-expression and self-realization. The children were invited to participate in the creation of theater and play plots, read aloud literary texts, reveal their positive emotions in relation to friends and close ones by means of play activities.

The "Systematist-Organizer". The diagnostic observation of such children allowed to identify such personality problems as the inability to evaluate the results of one's behavioral activity for others; the desire to impose their aspirations on others; attempts to dominate that do not correspond to the specific conditions of play activity. The relevant deficits were as follows: phonemic and semantic sensitivity to speech, full-fledged diction in oral speech, a variety of tactile sensations, and attention. To overcome these deficits, it is necessary to rely on the parameters of activity that are most comfortable for a given child (the development of spatial-temporal orientation, psychophysical endurance, intellectual and cognitive activity) (Akulova, 2009; Zinkevich-Evstigneeva \& Grabenko, 2008). 
Lover-1).

The "leading" subgroup ("Adventurer-Conman" - 2; "Leader-Manipulator" - 3; "Leader-Truth

The "Adventurer-Conman". The diagnostic results have confirmed such qualities of this psychotype as individualism and a tendency to observe their own benefits in different situations. The revealed deficits were as follows: interpersonal interaction, spatial-temporal orientation, phonemic and semantic sensitivity to speech, full-fledged diction in oral speech. They were overcome through such familiar aspects in interpersonal interaction as visual perception, attention, memory, motor skills, intellectual and cognitive activity. The diagnostic results have also confirmed the efficiency of this psychological and pedagogical strategy.

The "Leader-Manipulator". These children were characterized by poor controllability, hyperactivity, imposing their leadership on others and suppressing the initiative of others. The consequences of these negative manifestations were as follows: the insufficient development of visual perception, attention, memory, phonemic and semantic susceptibility to speech, intellectual and cognitive activity. These problems were solved by intensifying the aspects of interaction typical of this psychotype, including motor skills, spatial-temporal orientation, coordination and a variety of physical movements. Based on the results of these impacts, we have confirmed the possibility of compensating and solving these problems through the above-mentioned aspects of interpersonal interaction.

The "Leader-Truth Lover". The problems of these children included emotional tightness, difficulties in communicating with unfamiliar people, no sense of the appropriate manifestation of their behavior, fears of self-expression in front of a new audience. According to the diagnostic data, the development of interpersonal interaction skills is characterized by the following problems: motor skills, spatial-temporal orientation, coordination and a variety of physical movements. The compensatory aspects of interaction are visual perception, attention, memory, phonemic and semantic sensitivity to speech.

The "humanistic" subgroup ("Merciful Esthete" - 5, "Creator of Beauty" - 2; "Truth LoverHumanist"-2).

The "Merciful Esthete". The vulnerable aspects of their personality comprised the insufficient rationality of behavior (mostly depending on spontaneous emotional impulses); increased suggestibility and unpredictability of reactions. These features conditioned the underdevelopment of such aspects of interpersonal interaction as attention, psychophysical endurance, intellectual and cognitive activity. The immersion of these children into intensive informal communication represented as productive art and play activity contributes to the solution of the above-mentioned problems. Accordingly, it is necessary to provide these preschoolers with the opportunity to show their strengths, including visual perception, attention, memory, motor skills, spatial-temporal orientation, phonemic and semantic sensitivity to speech, coordination and a variety of physical movements, full-fledged diction in oral speech.

"The Creator of Beauty". Emotional restraint and isolation in combination with individualism make it difficult for such a child to communicate with the outside world. As compensation, these children were offered intensive activity on the creation of game programs and involvement in various motor activities. At the same time, it was recommended to rely on such strengths as visual perception, attention, memory, motor skills, spatial-temporal orientation, psychophysical endurance, coordination and a variety of physical movements. The diagnostics have shown that this strategy is promising.

The "Truth Lover-Humanist". Low self-esteem and fear of public self-demonstration significantly reduced the speech potential of these children. The negative factors that affected the emergence of such problems were as follows: underdeveloped motor skills, spatial-temporal orientation, a variety of tactile sensations and psychophysical endurance. To overcome the abovementioned deficits and problems in interpersonal interaction, the children should master such 
aspects as visual perception, attention, memory, full-fledged diction in oral speech, intellectual and cognitive activity (Panfilova, 1995).

\section{CONCLUSION}

1. The analysis of game activities aimed at the formation of interpersonal relations of senior preschoolers has shown that, along with general interaction between members of this age group, it is also necessary to consider the psychological characteristics of each child. Accordingly, it seems promising to single out subgroups with the greatest psychological compatibility within such collectives, which can significantly increase the effectiveness of pedagogical work with preschoolers who are incapable of proper relationships in group activities.

2. The organizational and methodological support of the corresponding empirical research should be based on a comprehensive diagnosis of the preschooler's personality, including the most significant parameters of the personal development of children.

3. The results of the primary diagnosis of interpersonal relationships among senior preschoolers open up new perspectives in the implementation of an integrated approach to pedagogical work with senior preschoolers.

Authors' Contributions: Natalia Sergeevna Yushchenko: designed the study, prepared the plan, wrote the first draft of the manuscipt and edited the final version. Elena Borisovna Pokivaylova: designed the study, prepared the plan, wrote the first draft of the manuscipt and edited the final version. Lena Igorevna Cheshenko: designed the study, prepared the plan, wrote the first draft of the manuscipt and edited the final version. Olga Victorovna Ershova: designed the study, prepared the plan, wrote the first draft of the manuscipt and edited the final version. Vladimir Manuilov: designed the study, prepared the plan, wrote the first draft of the manuscipt and edited the final version. All authors have read and approved the final version of the manuscript.

Ethics Approval: Not applicable.

Acknowledgments: Not applicable.

\section{REFERENCES}

Akulova, E. F. (2009). Didakticheskaya igra kak effektivnaya forma sozdaniya sotsialnoi situatsii razvitiya doshkolnikov [Didactic games as an efficient form of creating a social situation in developing preschool children]. Izvestiya Rossiiskogo gosudarstvennogo pedagogicheskogo universiteta im. A. I. Gertsena, 98, 9-17.

Bozhovich, L. I. (1998). Lichnost i ee formirovanie v detskom vozraste [Personality and its formation in childhood]. Moscow: Prosveshchenie, $321 \mathrm{p}$.

Dalceggio, M. M., \& Rodríguez, N. B. (2021). Theory and practice in teacher training at UNLP: an analysis of the curriculum. Journal of Research and Knowledge Spreading, 2(1), e12303.

Elkonin, D. B., \& Venger, A. L., Eds. (1988). Osobennosti psikhologicheskogo razvitiya detei 6-7 letnego vozrasta [The specific psychological development of children aged between six and seven years]. Moscow: Prosveshchenie, $256 \mathrm{p}$.

Goffman, E. (2004). Analiz freimov [Frame analysis]. Moscow: In-t sotsiologii RAN.

Grishina, N. V., Compl. (2001). Psikhologiya sotsialnykh situatsii [The psychology of social situations]. Saint Petersburg: PITER.

Ilina, M. N. (2007). Podgotovka k shkole: razvivayushchie testy i uprazhneniya [School preparation: educational tests and exercises]. Saint Petersburg: Piter, 208 p.

Jung, C. G. (1995). Psikhologicheskie tipy [Psychological types]. Saint Petersburg: Yuventa, 716 p.

Kadson, H., \& Schaefer, C. (2001). Praktikum po igrovoi psikhoterapii [Practional course of play psychotherapy]. Saint Petersburg: Piter, 416 p.

Kamenets, A. V., Ed. (2014). Psikhologo-pedagogicheskie osnovy organizatsii detskogo tvorchestva [Psychological and pedagogical foundations of children's creative work]. Moscow: Izd-vo "Radost", 42 p. 
Kamenets, A. V. (2015). Vvedenie v teoriyu sotsialnogo vzaimodeistviya [Introduction to the theory of social networking]: monograph. Moscow: Izd-vo RGSU, 464 p.

Kipnis, M. S. (2002). Dramaterapiya [Drama therapy]. Moscow: Os-89, 192 p.

Knyazeva, O. L. (2003). Ya-Ty-My. Programma sotsialno-emotsionalnogo razvitiya doshkolnikov [I-You-We. The program of social and emotional development of preschool children]. Moscow: Mozaika-Sintez, 168 p.

Leontev, A. N. (2009). Psikhologicheskie osnovy razvitiya rebenka i obucheniya [Psychological foundations of developing and teaching children]. Moscow: Smysl, $426 \mathrm{p}$.

Leutz, G. (1994). Psikhodrama. Teoriya i praktika. Klassicheskaya psikhodrama Ya.L. Moreno [Psychodrama. Theory and practice. Classical psychodrama of J.L. Moreno]. Moscow: Izdat gruppa "Progress", "Univers".

Loginova, V. I., \& Samorukova, P. G., Eds. (1988). Doshkolnaya pedagogika [Preschool pedagogy]. In two parts. Part Two. Moscow: Prosveshchenie, $256 \mathrm{p}$.

Moreno, J. (2001). Psikhodrama [Psychodrama]. Moscow: Aprel Press, izd-vo EKSMO-Press.

Mukhina, V. S. (2010). Detskaya psikhologiya [Child psychology]. Moscow: Akademiya, 315 p.

Panfilova, M. A. (1995). Igry i uprazhneniya dlya razvitiya navykov obshcheniya u doshkolnikov [Games and exercises for developing the communication skills of preschool children]. Minsk: Scaryna, $75 \mathrm{p}$.

Smirnova, E. O., \& Kholmogorova, V. M. (2003). Mezhlichnostnye otnosheniya doshkolnikov: diagnostika, problemy, korrektsiya [Interpersonal relationships of preschool children: diagnosis, problems and correction]. Moscow: Vlados, $160 \mathrm{p}$.

Zinkevich-Evstigneeva, T. D., \& Grabenko, T. M. (2008). Igry v skazkoterapii [Games in fairy tale therapy]. Saint Petersburg: Izd. Rech, 208 p.

Received: 31 May 2021 | Accepted: 13 July 2021 | Published: 27 July 2021 